\title{
Intelectuais e reforma do Judiciário: os especialistas em direito processual e as reformas da justiça no Brasil
}

Intellectuals and reform of the judicial system: procedural law experts and reforms of Justice in Brazil

O objetivo do presente artigo é demonstrar a relevância política do direito processual nas reformas do sistema de justiça brasileiro, bem como o papel político exercido pelos especialistas em direito processual na concepção e na condução dessas reformas. Com isso, e para além de sua contribuição específica para os estudos sobre o Judiciário brasileiro, este trabalho busca contribuir para os estudos sobre reformas do Estado em geral e também para os estudos sobre intelectuais e política no Brasil ${ }^{1}$.

No primeiro aspecto (a relevância política do direito processual nas reformas da justiça brasileira), ressalto as características institucionais do sistema de justiça brasileiro, que consideram a unidade nacional da legislação processual uma vantagem comparativa em relação à fragmentação das agências burocráticas e das carreiras profissionais responsáveis pela administração da justiça estatal. Meu argumento, nesse ponto, é estritamente institucional: à ausência de coordenação política da dimensão propriamente burocrática e profissional do sistema opõe-se a unidade da legislação processual.

Ao contrário da reforma constitucional do Poder Judiciário, a legislação processual pode ser reformada por processos legislativos de maioria simples; e também ao contrário da reforma de outras legislações infraconstitucionais que estruturam o sistema de justiça brasileiro (como as leis orgânicas

É professor doutor do Departamento de Ciência Política do Instituto de Filosofia e Ciências Humanas da Universidade Estadual de Campinas (SP). E-mail: almeidaf@unicamp.br.

Sobre a relação entre reforma do Judiciário e as reformas do Estado no Brasil, ver Sadek (1999; 2004a, 2004b). Sobre as relações entre intelectuais e política no Brasil, ver Miceli (1979; 1999). 
da magistratura e do Ministério Público ou o Estatuto da Advocacia), a reforma da legislação processual tende a enfrentar menos resistências de atores políticos organizados em lobbies corporativos. Essas características institucionais ajudam a compreender por que reformas constitucionais do Judiciário ou das leis orgânicas e estatutos das carreiras jurídicas foram tão pontuais e esparsas, ao passo que reformas da legislação processual foram muito mais frequentes na história republicana recente: a Emenda Constitucional n. 45/2004 realizou a Reforma do Judiciário após mais de dez anos de tramitação no Congresso Nacional; antes dela, a mais importante reforma institucional do Judiciário havia sido feita em 1977, em regime autoritário, por meio do chamado "Pacote de Abril"; a Lei Orgânica da Magistratura, instituída na sequência daquele conjunto de mudanças, em 1979, até hoje não foi revisada, apesar das críticas à sua origem autoritária; por fim, se a elaboração da Constituição de 1988 compreendeu um período de redefinições importantes para o sistema de justiça, historicamente localizado e excepcional, sua reforma não foi possível na revisão constitucional de 1993; por outro lado, os grandes problemas de acesso à justiça e eficiência do Judiciário, apontados desde a década de 1970, foram enfrentados pelas reformas processuais, especialmente a Lei da Ação Civil Pública, a Lei dos Juizados Especiais e as chamadas "minirreformas" do Código de Processo Civil das décadas de 1990 e $2000^{2}$.

No segundo aspecto (o papel político dos especialistas em direito processual nas reformas da justiça), desloco a análise de uma abordagem institucional para uma explicação baseada na existência do campo jurídico ${ }^{3}$, mais amplo que as instituições formais do sistema de justiça, no qual agentes que identifico como uma elite intelectual, sem necessariamente possuírem posições de liderança na estrutura estatal, mobilizam recursos de poder simbólico (capitais políticos, acadêmicos, profissionais) para garantirem acesso privilegiado aos processos políticos de reforma do sistema de justiça pela via processual.

Com raras exceções, se a literatura de ciência política sobre o acesso à justiça e a reforma do Judiciário brasileiro tem tratado abundantemente das reformas processuais (com destaque para os juizados especiais, a ação civil

Para um histórico dessas reformas e tentativas de reformas, ver Arantes (2002), Sadek (2004a) e Grinover (2005).

Para uma teoria do campo jurídico, ver Bourdieu (2007, cap. VIII); para uma sociologia do campo jurídico brasileiro, ver Engelmann (2006); para uma análise comparativa das concepções de sistema de justiça e de campo jurídico, ver Almeida $(2010,2014)$. 
pública e as ações diretas de constitucionalidade), ela possui duas lacunas consideráveis: a primeira é a de que pouco explora os aspectos institucionais que contrapõem a unidade da legislação processual à fragmentação burocrática e processual do sistema de justiça; a segunda é a de que, com exceção dos trabalhos de Luiz Werneck Viana et al. (1999) e Rogério Bastos Arantes (2002), dificilmente os especialistas em direito processual são tratados como atores políticos dos processos de reforma da justiça - como são, usualmente, a magistratura, a Ordem dos Advogados do Brasil (OAB) e o Ministério Público.

Dados de pesquisa sobre as elites jurídicas e a reforma do Judiciário ${ }^{4}$ mostram que um mesmo grupo de especialistas em direito processual, concentrado no Departamento de Direito Processual da Faculdade de Direito da Universidade de São Paulo (FDUSP), tem participação privilegiada nas comissões responsáveis pelos anteprojetos das reformas processuais centrais do período da redemocratização. As comissões foram o principal caminho escolhido pela justiça brasileira em sua história recente para sua reforma e modernização, que ocorreu por meio de inovações legislativas, como a Lei dos Juizados de Pequenas Causas, a Lei da Ação Civil Pública, o Código de Defesa do Consumidor, as reformas do Código de Processo Civil na década de 1990 e o pacote de reforma infraconstitucional do Poder Judiciário, lançado pelo Ministério da Justiça em 2003. Tal grupo, cujo núcleo intelectual é em geral identificado como "Escola Processual Paulista", relaciona-se com processualistas italianos, de outras regiões e escolas do Brasil e com especialistas tanto em processo civil como em processo criminal, por meio de redes que passam pelos intercâmbios culturais entre escolas diferentes, do trânsito de acadêmicos de outras escolas pelo programa de pós-graduação do Departamento de Direito Processual da FDUSP, da atuação no Instituto Brasileiro de Direito Processual (IBDP) e dos percursos acadêmicos e profissionais de seus próprios membros principais. Contudo, como demonstrarei, o protagonismo desse grupo não se dá sem conflitos internos e com outros grupos intelectuais e prático-profissionais do campo jurídico, além de haver arranjos e tensões com o campo político.

Este artigo é uma versão modificada do capítulo 5 de minha tese de doutorado (Almeida, 2010), no qual identifiquei e analisei o papel da Escola Processual Paulista nas reformas da justiça no Brasil. Busquei atualizar dados e desenvolvi argumentos e análises que não haviam sido feitas naquele momento, situando o objeto de estudo no contexto não somente das reformas judiciais, mas das reformas do Estado em geral e dos estudos sobre intelectuais e política. 
Meu argumento é o de que a posição de poder desse grupo intelectual está relacionada com as estratégias de seus membros nas relações com as demais posições de poder do campo jurídico, relativizando sua autonomia acadêmica por meio da relação com os "práticos" do direito, especialmente as carreiras jurídicas de Estado, a grande advocacia e os tribunais de cúpula do Judiciário. Além disso, para compreender a posição de poder conquistada pela Escola Processual Paulista na política da administração da justiça no Brasil, é preciso compreender também a gênese simbólica e as estratégias de reprodução interna do grupo e as próprias representações que seus membros fazem de seu pertencimento a ele.

\section{Direito processual e reforma da justiça}

Aquilo que cientistas políticos normalmente nomeiam de sistema de justiça é, na verdade, uma estrutura institucional fragmentada e com baixa coordenação ou centralização. O Poder Judiciário, estrutura nuclear do sistema de justiça brasileiro, compreende funções de justiças especializadas (trabalhista, militar, eleitoral) e comum (voltada para a litigiosidade civil e criminal em geral), cada qual com estruturas burocráticas (tribunais, carreiras, hierarquias) próprias. Embora a Constituição e a Lei Orgânica da Magistratura estabeleçam as bases nacionais para a organização da carreira judiciária, cada tribunal comum ou especializado tem considerável grau de autonomia administrativa e financeira e conta com regimentos próprios. Além disso, em termos jurisdicionais, os juízes de primeira instância, ou seja, os magistrados que individualmente processam os conflitos na "entrada" do sistema, detêm autonomia decisória praticamente absoluta, se sujeitando às suas cúpulas apenas em termos administrativos e de organização da carreira ${ }^{5}$.

Além dessa divisão, o Poder Judiciário no Brasil é dual, ou seja, há uma justiça federal (comum e especializada) e uma justiça estadual (comum e militar). Cada um desses ramos da justiça possui, como já dito, sua própria organização burocrática, composta pelas carreiras de magistrados e por tribunais de cúpulas que organizam essas carreiras e administram ainda toda a estrutura de apoio à função jurisdicional, incluindo o trabalho de ocupações correlatas, como os peritos, escreventes, analistas e técnicos judiciais. Cada

Para uma detalhada descrição da estrutura formal do sistema de justiça e suas instituições, ver Sadek (1999; 2004a). As disposições constitucionais sobre o sistema de justiça estão contidas nos capítulos III e IV da Constituiç̧ão Federal. 
justiça estadual tem seu tribunal de justiça local, ao passo que a justiça federal comum é organizada em cinco tribunais regionais federais (TRF); e a justiça federal especializada também possui tribunais regionais para cada ramo de atuação. Acima desses tribunais, há os chamados tribunais superiores, sediados em Brasília: o Superior Tribunal de Justiça (STJ), que serve de tribunal superior das justiças comuns estaduais e federal, além de exercer funções de controle administrativo sobre a justiça federal, por meio do Conselho da Justiça Federal (CJF); o Tribunal Superior do Trabalho (TST), o Supremo Tribunal Militar (STM) e o Tribunal Superior Eleitoral (TSE), que exercem as funções de última instância de recurso das justiças especializadas.

Acima de todos eles, está o Supremo Tribunal Federal (STF), chamado pela doutrina jurídica de tribunal de superposição ${ }^{6}$, pois pode se caracterizar como última e definitiva instância de recurso das causas processadas nas justiças comuns e especializadas, além de deter algumas competências originárias, não recursais, integralmente processadas em sua corte. O STF não possui autoridade administrativa sobre os tribunais e juízes abaixo dele posicionados (Falcão, 2005); ao contrário, sua posição de cúpula decorre mais de sua função jurisdicional, de última instância recursal em matéria constitucional, do que de seu poder administrativo sobre toda a pirâmide da justiça. Além disso, a composição do STF não se vincula à progressão de carreira da magistratura, e seus membros são indicados pelo presidente da República e aprovados pelo Senado.

Por outro lado, a Reforma do Judiciário de 2004 criou o Conselho Nacional de Justiça (CNJ) para exercer controle externo da atividade jurisdicional, em termos disciplinares, e estabelecer alguma forma de controle, padronização e planejamento administrativo de âmbito nacional sobre sua dispersa organização administrativa. O órgão é predominantemente composto de magistrados, embora haja participação da advocacia e do Ministério Público e algum equilíbrio entre conselheiros vindos das bases profissionais (embora indicados por suas cúpulas organizacionais) e membros de instâncias superiores.

Porém, o sistema de justiça não é apenas o Poder Judiciário. O Ministério Público, parte do sistema, organiza-se de forma estruturalmente correlata à do Judiciário, havendo um ministério público para cada ramo de justiça

Embora não seja essa uma posição consensual na doutrina jurídica; nesse sentido, ver Wagner Júnior et al (2006, p. 73). 
especializada, um Ministério Público Federal e os ministérios públicos dos estados da federação. Apesar desse paralelismo estrutural com o Poder Judiciário, que inclui a existência de uma lei orgânica própria, o Ministério Público adquiriu nas últimas décadas um campo de ação extrajudicial considerável, que exerce na defesa de direitos difusos, além de sua função constitucional de controle externo da polícia. A Reforma do Judiciário de 2004 também criou um órgão de controle externo e planejamento nacional do Ministério Público, que é o Conselho Nacional do Ministério Público (CNMP), com composição semelhante à do CNJ e predominância de membros da própria carreira.

A advocacia, por sua vez, também integra formalmente o sistema de justiça, uma vez que o artigo 133 da Constituição prevê que o advogado é indispensável à administração da justiça, e segundo o Estatuto da Advocacia (Lei n. 8.906/1994), a advocacia constitui função pública mesmo exercida em caráter privado. Ela é organizada por uma corporação oficial paraestatal, a $\mathrm{OAB}$, com bases federativas, havendo assim conselhos seccionais nos estados (as OAB estaduais) e um Conselho Federal (a OAB nacional). As OAB estaduais têm elevado grau de autonomia em relação à $O A B$ nacional, e é a partir dos conselhos seccionais, cujas direções são compostas por chapas diretamente eleitas pelos advogados inscritos, que se compõe politicamente o Conselho Federal, com a indicação de conselheiros federais pelas instâncias estaduais, que por sua vez elegerão o presidente nacional da entidade.

Além disso, em termos de oferta de serviços, os advogados privados, apesar de serem necessariamente inscritos nos quadros da OAB, podem atuar como profissionais liberais autônomos, associados ou empregados em escritórios e departamentos jurídicos de empresas. Há também a chamada advocacia pública, constituída pelos defensores públicos, que prestam assessoria jurídica gratuita à população, e pelos procuradores de autarquias e da administração direta do Estado. Apesar de em geral estarem organizados em carreiras públicas próprias, os advogados públicos também são inscritos na $\mathrm{OAB}$ e a ela se submetem em termos disciplinares e de regras gerais para o exercício profissional. Assim como ocorre com o Ministério Público, a atuação da advocacia pública e privada não é necessariamente atrelada à atividade jurisdicional do Estado, podendo haver atividades de consultoria e assessoria extrajudiciais, além da representação de interesses no âmbito administrativo. 
Percebe-se, portanto, que a expressão sistema de justiça busca abarcar uma realidade complexa, caracterizada por um sistema de partes, ou seja, o conjunto de instituições estatais e profissionais responsáveis pela oferta de serviços de justiça pelo Estado. Dessa forma, segundo Joaquim Falcão (2005, p. 23):

Entender o Poder Judiciário como um sistema significa também abandonar a visão de um poder unitário, para percebê-lo como um conjunto integrado por diversos "poderes". O que aparentemente era uno revela-se múltiplo. O que era integração aparece como fragmentação. O que era Poder Judiciário surge como vários "poderes judiciários”. No fundo, um sistema integrado de vários subsistemas. E isto coloca problemas e consequências graves para se posicionar diante da reforma.

Contudo, há um elemento de unificação desse sistema, que é o direito processual. O processamento de conflitos nas justiças especializadas obedece a regras processuais próprias (direito processual do trabalho, militar, eleitoral), de caráter nacional e, portanto, válidas para todas as agências e operadores desses ramos da justiça. A justiça comum, civil e criminal, exercida no âmbito federal ou estadual, também obedece a uma só legislação processual de caráter nacional - e é importante observar que a legislação processual comum também é aplicada subsidiariamente no âmbito das justiças especializadas.

Em termos legislativos, o direito processual brasileiro organiza-se em torno dos Códigos de Processo Civil e Penal e da legislação esparsa a eles relacionada; em termos doutrinários, define-se pela produção científica e acadêmica de juristas especializados na área. Antes da institucionalização burocrática e profissional das organizações estaduais e federais de justiça, a reforma da legislação processual era a principal via não só de gestão política da justiça estatal, como também da própria organização das relações políticas entre poderes locais e nacionais (Nunes Leal, 1975; Lima Lopes, 2001; Schneider, 2007; Coser, 2008). Mesmo com a institucionalização avançada dos sistemas de justiça estaduais e federal, com suas respectivas organizações burocráticas e profissionais dotadas de elevado grau de autonomia política, a via processual foi preferencialmente escolhida para a reforma da administração da justiça estatal, especialmente no período da redemocratização política recente (Paula, 2002). 
Nesse contexto, os especialistas em legislação processual, teóricos e práticos, são atores com acesso privilegiado às comissões de especialistas organizadas pelo Ministério da Justiça e pelo Congresso Nacional, para reforma e revisão dos códigos e da legislação processual esparsa. A participação dos especialistas em comissões dos poderes Executivo e Legislativo é prática tradicional do campo jurídico não só no que se refere à legislação processual, mas também à produção legislativa do direito material, ou seja, às normas que, antes de estabelecerem ritos de resolução de conflitos, estabelecem direitos "substantivos", infrações e sanções. Entretanto, acredito que o direito processual é uma dimensão particularmente importante para a compreensão da política da administração da justiça no Brasil, por dizer respeito diretamente à organização da atividade jurisdicional do Estado e aos poderes dos grupos de juristas profissionais em suas funções públicas; e, dentro do direito processual, o direito processual civil me parece especialmente relevante para se entender a administração e a reforma da justiça, pois na justiça civil tornam-se mais evidentes os problemas de acesso à justiça e segurança jurídica que orientaram a Reforma do Judiciário de 2004 (Cunha e Almeida, 2012) ${ }^{7}$.

\section{Gênese e poder da Escola Processual Paulista}

Os próprios representantes da Escola Processual Paulista costumam associar sua origem à vinda, em 1940, do processualista italiano Enrico Tullio Liebman para a FDUSP, na qual se refugiou, exilado do regime fascista italiano e da guerra na Europa. A denominação do grupo, e sua identificação como tal, inclusive com a declinação dos nomes de seus componentes, parece ter ocorrido, pela primeira vez, em artigo do também processualista Niceto Alcalá-Zamora y Castillo (1958) - ele mesmo um europeu exilado, inicialmente na Argentina e posteriormente no México, país que atribui a ele importância semelhante à de Liebman para o desenvolvimento do direito processual local ${ }^{8}$.

Isso não quer dizer que a justiça criminal não seja relevante para se compreender o sistema de justiça e suas dimensões de acesso, controle social e garantia de direitos; aliás, ignorar o peso da justiça criminal nos debates sobre administração e reforma da justiça tem sido uma falha comum dos estudos sobre reforma do Judiciário no Brasil. Nesse sentido, ver Sinhoretto e Almeida (2013).

8 Segundo Roberto Negrete Romero (s. d.): "A recepção na América Latina de vários intelectuais europeus, exilados por diversos conflitos políticos (que se tornariam bélicos) deflagrados em suas terras de origem, foi um dos maiores acertos das políticas exteriores e interiores de vários países. Personagens 
Mais do que associar sua origem como grupo à vinda de Liebman para o Brasil, os membros da Escola Processual Paulista veem naquele evento a própria origem de um direito processual com caráter verdadeiramente científico - definido, por seus praticantes, pelo rigor metodológico e pela influência da ciência processual italiana, referência internacional na área. Segundo Antônio Carlos de Araújo Cintra et al. (1998, p. 124), representantes da segunda geração da Escola Processual Paulista,

[...] o ingresso do método científico na ciência processual brasileira só pôde ter lugar mesmo, definitivamente, a partir do ano de 1940, quando para cá se transferiu o então jovem Enrico Tullio Liebman, já àquela época professor de direito processual civil na Itália. Nos seis anos que esteve entre nós, tendo inclusive sido admitido como professor visitante na Faculdade de Direito de São Paulo, foi Liebman o portador da ciência europeia do direito processual. Fora aluno de Chiovenda, o mais prestigioso processualista italiano de todos os tempos. Conhecia profundamente a obra dos germânicos, a história do direito processual e o pensamento de seus patrícios, notadamente do genial Carnelutti. Aqui, veio a dominar por interior a obra dos autores luso-brasileiros mais antigos e o espírito da legislação herdada de Portugal.

Liebman foi, durante esse tempo, um abnegado apóstolo de sua ciência.

A influência do direito processual italiano - mais especificamente do processualista Chiovenda, supracitado - já era acusada, no Brasil, desde o Código de Processo Civil de 1939, que, contudo, ainda guardava maiores conexões com os direitos processuais da Áustria, da Alemanha e de Portugal (Idem). Entretanto, para os membros da Escola Processual Paulista, a vinda de Liebman representou a efetiva interiorização da modernidade científica europeia no direito processual brasileiro e o estabelecimento de conexões diretas entre processualistas brasileiros e italianos:

Pelo que significou em toda essa evolução científica do direito processual no Brasil, foi Enrico Tullio Liebman agraciado pelo Governo Brasileiro, no ano de 1977, com

de grande vocação e imensa cultura - em diversos aspectos - vieram a revitalizar, e em muitos casos, a criar novas escolas de estudos e pensamento. Sendo mais específico, a ciência jurídica em vários países do continente americano se divide em duas etapas: antes e depois da estadia de intelectuais europeus trazidos pelo mar. Na ciência jurídico-processual podemos mencionar, brevemente: Enrico Tulio Liebman (radicado no Brasil), James Goldschmidt (acolhido no Uruguai), Santiago Sentís Melendo (na Argentina) e, claro, Niceto Alcalá-Zamora y Castillo no México, país que se tornaria sua segunda pátria" (traduzido livremente do original em espanhol). 
a Comenda da Ordem do Cruzeiro do Sul, máxima condecoração que se concede a personalidades estrangeiras beneméritas à nossa nação. [...] Graças ao estímulo sempre dado aos brasileiros na sua Universidade de Milão, foi possível celebrar um convênio cultural entre esta e a de São Paulo, no cumprimento do qual mestres de lá têm vindo ministrar cursos de pós-graduação aqui (Giuseppe Tarzia, Mario Pisani, Edoardo Ricci) e vice-versa (Ada Pellegrini Grinover, Cândido R. Dinamarco) (Idem, p. 125).

Entretanto, ao buscar sua identificação com as escolas europeias e italianas e, dessa forma, os membros da Escola Processual Paulista não deixaram de tentar estabelecer suas ligações também com a tradição brasileira do direito processual - por menos "científica" que ela fosse antes da vinda de Liebman. Essa estratégia de legitimação tentava situar a gênese simbólica e a identidade do grupo na passagem da tradição coimbrã ${ }^{9}$ para a modernidade científica, na qual surge a Escola Processual Paulista, num movimento ao mesmo tempo de continuidade (com a tradição de estudos processuais no Brasil) e de ruptura (com a ausência de método e rigor científico daqueles mesmos estudos). Em grande parte, o esforço de manutenção da tradição e de explicitação da continuidade está associado ao esforço de reprodução da posição de prestígio das duas mais antigas escolas de direito do Brasil e, principalmente, da Faculdade de Direito de São Paulo como centro cultural e político dominante no campo jurídico brasileiro:

O direito processual brasileiro sempre foi alvo de grande interesse entre os estudiosos brasileiros. Já no século passado tivemos processualistas como Pimenta Bueno (processo penal), o Barão de Ramalho e Paula Batista (ambos, processo civil), que deram início a um acervo cultural de que as gerações posteriores haveriam de orgulhar-se. O último deles, professor na Faculdade do Recife, é ainda hoje citado e considerado pela sua profunda percepção de problemas fundamentais do processo (ação, demanda, execução civil), descortinando horizontes ainda desconhecidos na própria processualística europeia de seu tempo.

Depois haveriam de vir Estevam de Almeida, João Monteiro e João Mendes Júnior, todos catedráticos de Direito Judiciário Civil na Faculdade de Direito de São Paulo, além de Galdino Siqueira, voltado ao processo penal. A cátedra de direito processual civil em São Paulo sempre exerceu verdadeiro fascínio sobre os juristas, dado o prestígio dos que a ocuparam e o interesse pela matéria. (Idem, p. 122)

Relacionada com a influência do ensino jurídico na Universidade de Coimbra, matriz portuguesa do ensino do direito no Brasil; nesse sentido, ver Alberto Venâncio Filho (2004) e Francisco Clementino de San Tiago Dantas (2009). 
Apesar disso, concluem os autores:

Mas a doutrina brasileira de então ressentia-se profundamente de uma grande desatualização metodológica. Nossos estudiosos, habituados à leitura dos clássicos portugueses (Correia Telles, Pereira e Souza, Lobão) e dos exegetas italianos (Mattirolo, Pescatore e mesmo Mortara), não se haviam alinhado ao movimento que a partir da metade do século passado [XIX] se instalara na Europa (Idem, p. 123).

Se a vinda de Liebman para o Brasil é o marco simbólico da gênese da Escola Processual Paulista, a fundação do Instituto Brasileiro de Direito Processual Civil, atual IBDP, em 1958, é o marco da institucionalização do grupo, o que permitiu que ele desdobrasse sua influência para além da FDUSP, alcançasse ramificações em outras faculdades de direito e setores profissionais jurídicos e observasse persistência no tempo, apesar da morte de seus fundadores - ainda assim, é importante observar que o instituto foi, desde sua fundação, formalmente incorporado à cadeira de direito judiciário civil daquela faculdade (Moreira Alves, 2003). A marca da Escola Processual Paulista, nesse grupo ampliado, pode se definir a partir do compartilhamento, por todos os integrantes, de

[...] certos pressupostos metodológicos fundamentais, como a relação jurídica processual (distinta e independente da relação substancial, ou res in judicium deducta), autonomia da ação, instrumentalidade do direito processual, inaptidão do processo a criar direitos e, ultimamente em certa medida, a existência de uma teoria geral do processo (Cintra et al., 1998, p. 124-5)10.

A evolução geracional, os desdobramentos intradisciplinares e os vínculos de pertencimento ou associação à Escola Processual Paulista podem ser verificados na citação de seus membros pelos pares, especialistas na área, como na ata de fundação do IBDP:

Aos quinze dias do mês de agosto do ano de mil novecentos e cinquenta e oito, na Faculdade de Direito de P. Alegre, da Universidade do Rio Grande do Sul, presentes o sr. Diretor, Prof. José Salgado Martins, e os srs. Professores Luiz Eulálio de Bueno Vidigal, Alfredo Buzaid, José Frederico Marques, Bruno de Mendonça Lima, Alcides

10 A defendida autonomia teórica e empírica do direito processual não pode deixar de ser considerada, ela mesma, um elemento discursivo importante para a constituição e a autonomização do grupo. 
de Mendonça Lima, Vicente Marques Santiago e Galeno Vellinho de Lacerda, foi decidida a fundação do Instituto Brasileiro de Direito Processual Civil (IBDPC). [...] A ideia de fundação do Instituto, que vinha sendo difundida nos meios universitários, encontrou caloroso acolhimento na sessão de encerramento dos trabalhos da

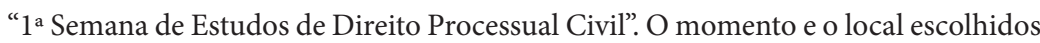
para a concretização daquela ideia, representam uma homenagem do Processualistas Brasileiros ao Estado do Rio Grande do Sul, que, no ano corrente, celebra o cinquentenário de promulgação do primeiro Código Estadual de Processo Civil elaborado no Brasil. O referido código, trabalho pessoal do ilustre dr. Antonio Augusto Borges de Medeiros, foi, a pedido deste, estudado, emendado e refundido por uma comissão de professores da então Faculdade Livre de Direito de Porto Alegre, tornando-se lei em 15 de janeiro de 1908 (IBDP, 2014).

\section{Também se verificam na referência de Cintra et al. (1998, p. 124):}

Vieram em seguida os trabalhos de alto nível de Luís Eulálio de Bueno Vidigal, Alfredo Buzaid e José Frederico Marques, discípulos de Liebman naqueles colóquios por este promovidos; de Moacyr Amaral Santos, de Celso Agrícola Barbi, de Alcides de Mendonça Lima, de Galeno Lacerda, de Moniz de Aragão, de Barbosa Moreira e de outros mais modernos, em processo civil. Em direito processual penal, destacaram-se o mesmo José Frederico Marques, Hélio Tornaghi, Fernando da Costa Tourinho Filho, Romeu Pires de Campos Barros. E, a partir de quando começou a haver interesse pelo direito do trabalho e pelo processo trabalhista, surgiram as obras processuais, nessa área, de Antônio Lamarca, de Coqueijo Costa, de Wagner Giglio, de Amauri Mascaro do Nascimento, de Wilson de Souza Campos Batalha.

Ou, ainda, na história do direito processual brasileiro feita por Jônatas Luiz Moreira de Paula (2002, p. 356):

Variantes do pensamento paulista se manifestaram nos estudos de José Joaquim Calmon de Passos, Ovídio A. Baptista da Silva, Aldroado Furtado Fabrício e Donaldo Armelin.

Modernamente, percebe-se que a Escola Paulista apresenta uma nova tendência, a instrumental, que se apresenta ao lado da tendência técnica, ainda vinculada com as origens da escola. A tendência instrumental, que especula as reformulações do processo por escopos políticos, sociais e jurídicos, tem entre seus integrantes nomes de escol, como Cândido Rangel Dinamarco e Ada Pellegrini Grinover, ambos vinculados à Universidade de São Paulo. 
A nova geração da escola abrange os estudos realizados por Teresa Alvim Wambier, Flávio Luis Yarshell, Kazuo Watanabe, Celso Neves, Vicente Grecco Filho, Antônio Carlos Marcato, José Carlos Barbosa Moreira, entre outros.

A transmissão de capitais simbólicos - especialmente do prestígio acumulados pelos fundadores do grupo se dá primordialmente por meio de relações pessoais diretas do tipo mestre-discípulo, sejam informais, sejam formalizadas por meio da relação orientador-orientando em programas de pós-graduação. Do primeiro caso, são exemplos as relações que vinculam Liebman a Alfredo Buzaid e Luís Eulálio Bueno Vidigal, seus alunos no curso de extensão que promoveu em seus primeiros anos em São Paulo, ou Buzaid a Cândido Rangel Dinamarco, seu assessor quando ministro da Justiça; do segundo, as relações existentes entre Vidigal e Ada Pellegrini Grinover e entre esta e Antonio Magalhães Gomes Filho e Maurício Zanóide de Moraes, ou entre Dinamarco e Antonio Carlos Marcato e Flávio Luiz Yarshell, conforme o Diagrama 1.

Diagrama 1 - Relações do tipo mestre-discípulo na Escola Processual Paulista

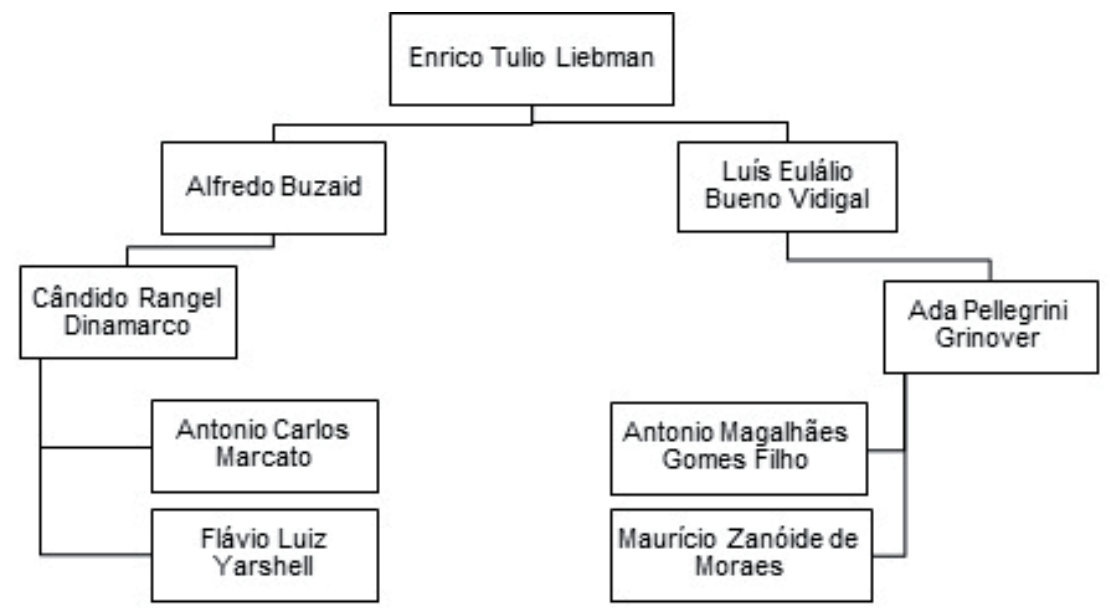

Fontes: CNPq (2014); ABDPC (2014); Alves (2003)

Em termos simbólicos, a reprodução da identidade do grupo, a partir da reativação de seus capitais transmitidos entre gerações e da consagração de novas e velhas gerações, se dá em grande parte por meio das publicações 
que constituem a obra cultural do grupo ${ }^{11}$. Um primeiro tipo de texto que cumpre essa função de transmissão vertical de capitais e de reprodução da identidade do grupo pode ser encontrado nos prefácios a livros "técnicos" de direito processual, por meio dos quais um membro do grupo, já consagrado e mais bem posicionado, introduz o autor prefaciado naquele universo e, consequentemente, em suas próprias redes de relações, consagrando-o. Um exemplo é o prefácio de Luís Eulálio de Bueno Vidigal ([1974] 1998), da primeira geração da Escola Processual Paulista, à primeira edição de livro que viria a ser uma referência na área, escrito pelos então "jovens mestres" Antônio Carlos de Araújo Cintra, Cândido Rangel Dinamarco e Ada Pellegrini Grinover, que viriam, com o passar dos anos, suceder o autor do prefácio na liderança daquele grupo intelectual:

Em todas as matérias versadas o novo compêndio mantém-se em alto nível científico. Os mestres que o elaboraram, que tão cedo, se demonstram dignos dos mais altos postos da carreira universitária, terão, estou certo, na consagração de seus alunos e no respeito de seus colegas o justo prêmio pelo bem empregado esforço em prol do ensino de sua disciplina (Idem, p. 6).

No sentido inverso dessa transmissão vertical de capitais entre homenageados e homenageantes é possível citar, como exemplos, os "estudos em homenagem" a José Frederico Marques, um dos fundadores da Escola Processual Paulista, organizados por Ada Pellegrini Grinover (1982), e à própria Ada Pellegrini Grinover, da segunda geração da escola, organizados por Flávio Luiz Yarshell e Maurício de Zanoide de Moraes (2005), pertencentes à geração seguinte. Tais coletâneas em homenagem aos antecessores ou superiores na hierarquia de prestígio misturam artigos "técnicos" da área de atuação dos homenageados com relatos biográficos e depoimentos sobre eles. Com o mesmo efeito de consagração e reativação de capitais de gerações anteriores, é possível citar os ensaios biográficos de especialistas em direito processual escritos por outros juristas, seja quando ambos pertencem à Escola

\footnotetext{
11 A análise dessas obras e de sua função simbólica de consagração inspira-se no estudo de Sergio Miceli (1988) sobre a elite eclesiástica brasileira, especialmente sobre o trabalho de consagração de bispos por seus subordinados ou assistentes mais próximos, que por sua vez esperavam com esse trabalho associar-se ao indivíduo consagrado e com isso abrir a possibilidade de substituí-lo na posição de elite. Para um desenvolvimento mais detalhado e aprofundado das possibilidades de aplicação dessa análise no estudo das elites jurídicas, ver Almeida (2010, cap. 2).
} 
Processual Paulista; seja quando um jurista "externo" reconhece a posição do membro da escola homenageado; seja, por fim, quando um membro da escola pretende estabelecer conexões com processualistas anteriores ou externos à escola e, então, evidencia a continuidade em relação à tradição brasileira. Tendo por base os relatos biográficos contidos nos dois livros da obra Grandes juristas brasileiros (Rufino e Penteado, 2003, 2006), é possível citar como exemplo: da primeira situação a biografia de Moacyr Amaral Santos, escrita por Rogério Lauria Tucci (2006); do segundo caso, os relatos sobre Alfredo Buzaid e José Frederico Marques, escritos, respectivamente, por José Moreira Alves (2003) e José Renato Nalini (2003); da terceira situação, o ensaio sobre o conselheiro Antonio Joaquim Ribas, escrito por José Rogério Cruz e Tucci (2003).

Embora a institucionalização da Escola Processual Paulista como grupo de referência no campo jurídico esteja diretamente relacionada com um processo relativamente incipiente de institucionalização do campo acadêmico do direito - por meio da criação de programas de pós-graduação em direito processual, com destaque para os das FDUSP e da Pontifícia Universidade Católica de São Paulo (PUC-SP) -, sua legitimidade não decorre exclusivamente do título acadêmico e do capital acumulado na atividade de pesquisa e ensino, mas de uma combinação dos capitais produzidos nesse tipo de trajetória intelectual com a experiência prático-profissional, presente na trajetória dos juristas diretamente envolvidos na aplicação do direito processual. Se compararmos esse caso brasileiro com a situação dos "notáveis" da academia jurídica francesa, cujo conflito com os advogados "práticos” foi analisado por Yves Dezalay e David Trubek (1996), é possível afirmar como hipótese que, ao contrário do que ocorreu na França, foi essa estratégia de constituição e reprodução da Escola Processual Paulista que impediu sua caracterização como grupo estritamente "teórico" e seu possível deslocamento em favor da ascensão e do posicionamento de grupos de "práticos".

Ao contrário dos notáveis acadêmicos franceses, portanto, a vinculação com o mundo prático-profissional do direito, no caso dos juristas da Escola Processual Paulista, parece ser constitutiva do grupo, desde sua origem, como se vê das trajetórias profissionais de seus membros de diversas gerações (Quadro 1). Além disso, especialmente por meio da socialização no IBDP, da realização de cursos e eventos temáticos (muitos deles voltados para o aper- 
feiçoamento profissional) ${ }^{12}$ e da influência das obras acadêmicas da Escola no trabalho cotidiano dos juristas "práticos" - é sempre importante lembrar o peso do argumento de autoridade na redação técnica e científica no direito, voltada para a defesa de teses aplicáveis a casos concretos (Oliveira, 2004; Nobre, 2005) -, a aliança entre agentes com trajetórias predominantemente acadêmicas e outros com trajetórias eminentemente prático-profissionais pode ser considerada o principal mecanismo de legitimação desse grupo contra o discurso, corrente no campo jurídico e contrário a discursos puramente teóricos, de que "quem entende do funcionamento da justiça é quem trabalha com ela”, empregado especialmente por juízes e advogados de "nível de rua"13.

Mais do que um discurso de resistência, contudo, a aliança teóricos- práticos executada pelos membros da Escola Processual Paulista e do IBDP, é capaz de explicar o sucesso desse grupo no acesso aos tribunais superiores e a comissões de reforma legislativa, como se vê no Quadro 1.

O Quadro 1 inclui a participação de membros do IBDP na elaboração de projetos de leis efetivamente promulgadas, outros que serviram de base para a legislação vigente, com modificações, e outros ainda que sequer saíram do papel. Isso demonstra que o poder desse grupo em muitos casos pode se limitar ao acesso às comissões para elaboração ou revisão legislativa, encontrando resistências nas próprias contingências da política e da tramitação legislativa para ter seus projetos finalmente aprovados, sem alterações. No primeiro caso - de projetos vitoriosos - é possível citar: o próprio Código de Processo Civil, de autoria de Alfredo Buzaid, com participação de José Frederico Marques; o Código de Defesa do Consumidor, cuja elaboração contou com a participação de Kazuo Watanabe e Ada Pellegrini Grinover; e a Lei dos Juizados Especiais Cíveis e Criminais, com colaboração de Antonio

12 Nesse sentido, ver as publicações resultantes dos seminários promovidos pela Secretaria de Reforma do Judiciário, em parceria com o IBDP, para sensibilização da comunidade jurídica para a reforma infraconstitucional do Poder Judiciário: Secretaria da Reforma do Judiciário do Ministério da Justiça (2005a; 2005b; 2005c) e Escola Nacional da Magistratura et al. (2006).

13 A expressão "burocracia de nível de rua" (street-level bureaucracy) é utilizada por Michael Lipsky (1980) para caracterizar as posições de burocracias prestadoras de serviços públicos diretamente atuantes na oferta desses serviços e com maior contato com seus usuários. O discurso de "quem entende de justiça é quem trabalha com ela"foi recorrente entre advogados e magistrados durante todo o período de reformas da justiça nas décadas de 1980 e 1990, sendo utilizado por aqueles dois grupos ora em situação de aliança contra iniciativas externas de reforma, ora em situação de oposição entre eles, em geral na crítica dos advogados ao alheamento de juízes e tribunais em relação aos problemas cotidianos de funcionamento da justiça; nesse sentido, ver Almeida (2006). 
Magalhães Gomes Filho. O melhor exemplo da segunda situação - de contribuições parciais para o resultado legislativo final - talvez seja o anteprojeto da Lei da Ação Civil Pública, elaborada por comissão com participação de Grinover, Watanabe e Cândido Rangel Dinamarco (além de Waldemar Mariz de Oliveira Júnior), e que serviu de base para outro projeto, apresentado pelo Ministério Público do estado de São Paulo e aprovado no Congresso Nacional (Arantes, 2002). Por fim, entre os anteprojetos que não resultaram em lei, o caso mais emblemático é o do Código de Processo Penal elaborado por José Frederico Marques, na década de 1970 (Nalini, 2003).

Quadro 1 - Trajetórias acadêmicas e profissionais e participação em reformas dos membros do IBDP

\begin{tabular}{|c|c|c|c|}
\hline nome & trajetória acadêmica & trajetória profissional & $\begin{array}{l}\text { participação em } \\
\text { reformas legislativas }\end{array}$ \\
\hline Alfredo Buzaid & $\begin{array}{l}\text { Bacharel (1935) e } \\
\text { livre-docente (1946) pela } \\
\text { FDUSP; professor e diretor } \\
\text { da FDUSP }\end{array}$ & $\begin{array}{l}\text { Advogado e ministro do } \\
\text { Supremo Tribunal Federal }\end{array}$ & $\begin{array}{c}\text { Autor do Código de Processo } \\
\text { Civil (1973); coordenador da } \\
\text { Comissão de Revisão de Códigos } \\
\text { (1967) }\end{array}$ \\
\hline $\begin{array}{l}\text { José Frederico } \\
\text { Marques }\end{array}$ & $\begin{array}{l}\text { Bacharel (1933) e livre-do- } \\
\text { cente (1953) pela FDUSP; } \\
\text { professor das faculdades de } \\
\text { direito da PUC-SP e a USP }\end{array}$ & $\begin{array}{l}\text { Advogado; juiz de direito e } \\
\text { desembargador do Tribunal } \\
\text { de Justiça do estado de } \\
\text { São Paulo }\end{array}$ & $\begin{array}{l}\text { Membro da Comissão do Código } \\
\text { de Processo Civil (1973); relator } \\
\text { do anteprojeto do Código de } \\
\text { Processo Penal (1970); membro } \\
\text { de comissão de elaboração de } \\
\text { projeto para a parte especial do } \\
\text { Código Penal (1970) }\end{array}$ \\
\hline $\begin{array}{l}\text { Cândido Rangel } \\
\text { Dinamarco }\end{array}$ & $\begin{array}{l}\text { Bacharel (1960), doutor } \\
\text { (1970), livre-docente } \\
\text { (1973) e professor pela } \\
\text { FDUSP }\end{array}$ & $\begin{array}{l}\text { Assessor do ministro da } \\
\text { Justiça Alfredo Buzaid; } \\
\text { desembargador do Tribunal } \\
\text { de Justiça do estado de } \\
\text { São Paulo }\end{array}$ & $\begin{array}{l}\text { Membro da Comissão do Minis- } \\
\text { tério Público de São Paulo para } \\
\text { análise e emendas ao antepro- } \\
\text { jeto de Código de Processo Penal } \\
\text { (1977); Membro de comissão de } \\
\text { elaboração de anteprojeto da } \\
\text { Lei da Ação Civil Pública (1985); } \\
\text { redator do anteprojeto de lei } \\
\text { de implantação do Juizado de } \\
\text { Pequenas Causas no estado de } \\
\text { São Paulo (1985) }\end{array}$ \\
\hline
\end{tabular}


Quadro 1 - Trajetórias acadêmicas e profissionais e participação em reformas dos membros do IBDP (continuação)

\begin{tabular}{|c|c|c|c|}
\hline nome & trajetória acadêmica & trajetória profissional & $\begin{array}{l}\text { participação em } \\
\text { reformas legislativas }\end{array}$ \\
\hline $\begin{array}{l}\text { Ada Pellegrini } \\
\text { Grinover }\end{array}$ & $\begin{array}{l}\text { Bacharel (1958), especialis- } \\
\text { ta (1966), doutora (1970) } \\
\text { e livre-docente (1973) da } \\
\text { FSUSP; professora das facul- } \\
\text { dades de direito de Vitória } \\
\text { e da USP }\end{array}$ & $\begin{array}{l}\text { Advogada; consultora jurí- } \\
\text { dica; procuradora do estado } \\
\text { de São Paulo; assessora } \\
\text { técnica do vice-governador } \\
\text { do Estado de São Paulo; } \\
\text { chefe da Consultoria } \\
\text { Jurídica da Secretaria de } \\
\text { Justiça do Estado de São } \\
\text { Paulo; assessora jurídica } \\
\text { do senador José Ignácio } \\
\text { Ferreira }\end{array}$ & $\begin{array}{l}\text { Membro de comissão de } \\
\text { elaboração de anteprojeto } \\
\text { de Lei da Ação Civil Pública } \\
\text { (1985); presidente da comissão } \\
\text { elaboradora do anteprojeto do } \\
\text { Código de Defesa do Consumidor } \\
\text { (1990) presidente da Comissão } \\
\text { de Reforma do Código de } \\
\text { Processo Penal (2000); membro } \\
\text { da Comissão de Revisão da Lei } \\
\text { da Ação Civil Pública (2008); } \\
\text { autora do projeto de lei do Poder } \\
\text { Executivo sobre quebra de sigilo } \\
\text { telefônico (2008) }\end{array}$ \\
\hline Kazuo Watanabe & $\begin{array}{l}\text { Bacharel (1959), especia- } \\
\text { lista (1969 e 1970), mestre } \\
\text { (1978), e doutor (1985) } \\
\text { pela FDUSP; professor das } \\
\text { faculdades de direito de } \\
\text { Guarulhos, da USP e das } \\
\text { Faculdades Metropolitanas } \\
\text { Unidas }\end{array}$ & $\begin{array}{l}\text { Advogado; consultor } \\
\text { jurídico; desembargador } \\
\text { do Tribunal de Justiça de } \\
\text { São Paulo }\end{array}$ & $\begin{array}{l}\text { Membro da comissão elabo- } \\
\text { radora do anteprojeto da Lei } \\
\text { Federal de Pequenas Causas } \\
\text { (1984); membro de Comissão } \\
\text { de elaboração de anteprojeto da } \\
\text { Lei da Ação Civil Pública (1985); } \\
\text { membro da comissão de revisão } \\
\text { do Código de Processo Civil } \\
\text { (1985); membro da comissão } \\
\text { elaboradora do projeto de lei } \\
\text { estadual de criação do Sistema } \\
\text { dos Juizados Especiais das Pe- } \\
\text { quenas Causas (1986); membro } \\
\text { da comissão elaboradora do } \\
\text { anteprojeto do Código de Defesa } \\
\text { do Consumidor (1990); membro } \\
\text { da comissão elaboradora e } \\
\text { revisora dos projetos de reforma } \\
\text { do Código de Processo Civil } \\
\text { (1994-1995); }\end{array}$ \\
\hline
\end{tabular}


Quadro 1 - Trajetórias acadêmicas e profissionais e participação em reformas dos membros do IBDP (continuação)

\begin{tabular}{|c|c|c|c|}
\hline nome & trajetória acadêmica & trajetória profissional & $\begin{array}{l}\text { participação em } \\
\text { reformas legislativas }\end{array}$ \\
\hline $\begin{array}{l}\text { Antônio Maga- } \\
\text { Ihães Gomes } \\
\text { Filho }\end{array}$ & $\begin{array}{l}\text { Bacharel (1970), mestre } \\
\text { (1982), doutor (1989) e } \\
\text { livre-docente (1995) pela } \\
\text { FDUSP; especialista (1973) } \\
\text { pela PUC-SP; professor } \\
\text { e vice-diretor da FDUSP; } \\
\text { professor das faculdades } \\
\text { de direito da Universidade } \\
\text { de Taubaté, de Osasco e de } \\
\text { Itapetininga }\end{array}$ & $\begin{array}{l}\text { Membro do Ministério } \\
\text { Público do Estado de São } \\
\text { Paulo }\end{array}$ & $\begin{array}{l}\text { Membro de comissão de elabora- } \\
\text { ção de anteprojeto sobre custó- } \\
\text { dia provisória formulado pela } \\
\text { Secretaria da Segurança Pública } \\
\text { de São Paulo (1983); membro } \\
\text { da comissão formada pela Pro- } \\
\text { curadoria Geral de Justiça e pela } \\
\text { Associação Paulista do Ministério } \\
\text { Público para oferecer estudos } \\
\text { e sugestões sobre o projeto de } \\
\text { Código de Processo Penal (1983); } \\
\text { membro da Comissão de Estudos } \\
\text { sobre Alterações na Legislação } \\
\text { Processual Penal, instituída pela } \\
\text { Associação Paulista do Ministério } \\
\text { Público (1992); membro da } \\
\text { Comissão Revisora da Reforma } \\
\text { do Código de Processo Penal do } \\
\text { Ministério da Justiça (1994); } \\
\text { membro do Grupo de Trabalho } \\
\text { da Secretaria da Administração } \\
\text { Penitenciária do Estado de } \\
\text { São Paulo para alterações na } \\
\text { Lei de Execução Penal. (1995); } \\
\text { membro da comissão formada } \\
\text { por professores da USP e juízes } \\
\text { do Tribunal de Alçada Criminal } \\
\text { de São Paulo para elaboração de } \\
\text { anteprojeto da Lei dos Juizados } \\
\text { Especiais Cíveis e Criminais } \\
\text { (1995); membro da Comissão de } \\
\text { Reforma do Código de Processo } \\
\text { Penal do Ministério da Justiça } \\
\text { (2000); membro Procesasso Penal (2008) } \\
\text { juristas do Senado Federal para anteprojeto de }\end{array}$ \\
\hline
\end{tabular}


Quadro 1 - Trajetórias acadêmicas e profissionais e participação em reformas dos membros do IBDP (continuação)

\begin{tabular}{|c|c|c|c|}
\hline nome & trajetória acadêmica & trajetória profissional & $\begin{array}{l}\text { participação em } \\
\text { reformas legislativas }\end{array}$ \\
\hline $\begin{array}{l}\text { Tereza Arruda } \\
\text { Alvim Wambier }\end{array}$ & $\begin{array}{l}\text { Bacharel (1980), mestre } \\
\text { (1985), doutora (1990) } \\
\text { e livre-docente (2004) } \\
\text { pela PUC-SP; professora } \\
\text { da PUC-SP, da PUC-PR, da } \\
\text { Universidade Paranaense } \\
\text { e Universidade Tuiuti do } \\
\text { Paraná, e das Faculdades } \\
\text { Integradas de Curitiba }\end{array}$ & $\begin{array}{c}\text { Advogada; consultora } \\
\text { jurídica }\end{array}$ & $\begin{array}{c}\text { Relatora da comissão de juristas } \\
\text { do Senado Federal para elabora- } \\
\text { ção do anteprojeto de Código de } \\
\text { Processo Civil (2009) }\end{array}$ \\
\hline
\end{tabular}

Fontes: Supremo Tribunal Federal (2014); CNPq (2014); Alves (2003); Nalini (2003); Arantes (2002).

Ainda com essas limitações, é relevante a contribuição do IBDP e da Escola Processual Paulista para a política recente do Estado brasileiro em relação ao direito processual - se não pela importância dos casos de sucesso listados acima, que por si só constituem o eixo das reformas processuais no Brasil desde a década de 1970, ao menos pela recorrência com que seus membros são recrutados pelo Estado para a elaboração de projetos de revisão ou inovação legislativa, independentemente do resultado. Nesse sentido, Grinover (2005) cita 21 leis que reformaram pontualmente o Código de Processo Civil de 1973, promulgadas entre 1992 e 2002, todas elas originárias do IBDP; também no site do órgão (IBDP, 2014) é possível identificar diversas propostas legislativas de direito processual civil e penal apresentadas por seus representantes, várias delas já transformadas em lei - incluindo o anteprojeto de um Código Brasileiro de Processos Coletivos, este ainda em tramitação no Congresso.

Além do capital acadêmico representado pelo reconhecimento e pelo prestígio acumulado por meio da produção doutrinária do grupo dos processualistas - o capital científico "puro", segundo Bourdieu (2004) -, a participação de seus membros nas comissões de elaboração legislativa - base não só do funcionamento da justiça estatal, mas de sua própria produção doutrinária em direito processual positivo - reforçou outro tipo de capital científico, já acumulado pela Escola Processual Paulista à medida que seus 
representantes alcançaram os cargos mais altos da hierarquia acadêmica: o capital científico-institucional que, segundo Bourdieu (2004), decorre do controle alcançado pelos agentes do campo científico dos meios de produção científica e de desenvolvimento de carreiras acadêmicas.

\section{Dimensões e densidades de um grupo intelectual}

A partir do episódio da polêmica em torno da autoria do anteprojeto de um Código Brasileiro de Processos Coletivos - que, a exemplo do Código de Processo Civil de Buzaid, de 1973, coroaria os investimentos da nova geração da Escola Processual Paulista e consolidaria seu poder na área da tutela judicial de interesses coletivos - é possível extrair um ilustrativo exemplo das dimensões e das fronteiras que um grupo intelectual pode assumir nas suas relações com outros intelectuais e com o Estado.

Analisando as diversas formas de organização possíveis da intelligentsia, Karl Mannheim (1957, p. 180) afirma:

Entre as organizações compactas e em forma de casta, por um lado, e o grupo aberto e sem coesão, por outro, existem numerosos tipos intermediários de conglomerados nos quais os intelectuais podem congregar-se. Seus contatos mútuos são com frequência informais, mas o grupo reduzido, íntimo, constitui o padrão mais frequente. Tem desempenhado um papel eminentemente catalítico na formação de atitudes comuns e de correntes de pensamento.

Para Mannheim, o protagonismo dos grupos íntimos (ou reduzidos) se deve justamente à densidade de suas redes de relacionamento (entre seus membros e entre eles e seus patronos, sejam mecenas privados ou o Estado) e à maior capacidade de seleção de seus membros. Assim, é possível dizer que a Escola Processual Paulista é um grupo íntimo, caracterizado pela organização informal em redes de relacionamento entre seus membros e entre esses e seus patronos (nesse caso, o Estado), enquanto o IBDP é a organização formal de referência de um grupo ampliado, representado por todo o campo de especialistas em direito processual que comungam das posições doutrinárias da escola.

Afinal, a Escola Processual Paulista pode ser considerada o núcleo ideológico e histórico de um grupo intelectual influente na teoria jurídica processual e na administração da justiça estatal, cuja expansão e incorporação de outros 
agentes se deram principalmente pela criação do IBDP e pela institucionalização e reprodução do prestígio acumulado por aquele núcleo. Além disso, as redes de relações entre os membros da Escola, de diferentes gerações, e entre eles, o Estado e as carreiras jurídicas reforçam características apontadas por Mannheim para a caracterização de um grupo reduzido de intelectuais e de sua influência na formação de correntes de pensamento - no caso, de uma corrente predominante de doutrina jurídica processual, com reflexos na política da justiça estatal. A referida polêmica em torno do anteprojeto do Código Brasileiro de Processos Coletivos ajuda a compreender como se dá a relação entre a forma reduzida e a forma ampliada de um grupo intelectual, bem como a importância das redes de relações e da seleção restrita de membros para o reforço de suas fronteiras originais, a sua reprodução e a reafirmação da autoridade do grupo íntimo sobre o grupo ampliado. Tal polêmica teve início com o convite do processualista Antonio Gidi (2008) para o lançamento de seu livro Rumo a um Código de Processo Civil coletivo; o texto do convite reproduzia parte do texto existente na contracapa do livro:

Com um misto de lisonja e consternação, vemos processualistas criticando nossas ideias, mas atribuindo sua autoria a outras pessoas. Comentam-se os anteprojetos derivados (Ibero-Americano, USP e Uerj/Unesa) ignorando o original que, publicado vários anos antes, deu origem e foi a inspiração dos posteriores.

Ao apresentar a história da codificação do processo coletivo e criticar as posições dos anteprojetos derivados, buscamos (re)inserir ideias originais e inovadoras no debate nacional e (re)estabelecer a autoria daquelas que são equivocadamente atribuídas a outros autores.

Todavia, o real objetivo em publicar estas anotações não é simplesmente fazer um exame de DNA, para provar a paternidade intelectual das nossas contribuições. O que nos motiva é principalmente o receio de que, sem uma visão crítica dos anteprojetos derivados, haja risco iminente de que o Brasil promulgue legislação inadequada. Como recentemente o Instituto Brasileiro de Direito Processual encampou o Anteprojeto USP e o remeteu para o Ministério da Justiça, comentamos as principais normas dos anteprojetos derivados através de uma crítica cruamente franca e intelectualmente honesta.

O caminho rumo à codificação processual coletiva ainda é incerto mas, sem dúvida, inevitável. O Brasil terá o CPC Coletivo que merece. Se ele será um modelo de técnica legislativa para os demais países, ou uma demonstração internacional de mediocridade, essa é uma história em construção. 
Antonio Gidi é graduado em direito pela Universidade Federal da Bahia, instituição que, embora ocupe posição de destaque nas hierarquias escolares do campo jurídico, está fora do núcleo acadêmico originário da Escola Processual Paulista, definido em torno da FDUSP e da PUC-SP. Por outro lado, transitou pelas redes de relações que definem a Escola Processual Paulista como um grupo intelectual de poder; obteve seus títulos de mestre e de doutor em direito processual pela PUC-SP (sob orientação de Thereza Celina Arruda Alvim, conselheira do IBDP e mãe de Tereza Arruda Alvim Wambier, citada no Quadro 1) e trabalhou, no desenvolvimento do referido anteprojeto de Código de Processos Coletivos, com Kazuo Watanabe e Ada Pellegrini Grinover, dois expoentes da Escola. Como se percebe na transcrição, a polêmica levantada por Gidi tem a ver justamente com o reconhecimento da autoria de um anteprojeto legislativo - e, em última análise, com o reconhecimento de seu próprio pertencimento ao grupo intelectual de poder.

A resposta de Ada Pellegrini Grinover ao texto do convite traça um histórico da legislação de direito processual na área da tutela coletiva no Brasil - e, mais do que isso, do protagonismo da autora e de seu grupo na elaboração dessa legislação. Foi publicada na página do Instituto Brasileiro de Direito Processual na internet (Grinover, 2008). Em sua resposta, a autora buscou situar Gidi em relação ao núcleo de poder do grupo intelectual original (o grupo íntimo) e nas hierarquias de poder do campo de produção acadêmica em direito processual:

Entendo a "consternação" do Autor, que não viu mencionado pela doutrina seu "projeto original", que teria "dado origem e inspirado os posteriores" (mas pergunto: é a doutrina ou o projeto responsável pelo silêncio? Quando apareceu Antonio Gidi no cenário nacional como especialista em processos coletivos?). [...]

Em maio de 2002, quando o minissistema brasileiro de processos coletivos estava em pleno funcionamento, surgiu a ideia de um Código Modelo de Processos Coletivos para Ibero-América. Esta sim, devida e sempre reconhecida como sendo de Antonio Gidi. Em Roma, durante o VII Seminário Internacional coorganizado pelo Centro di Studi Giuridici Latino Americani da Università degli Studi di Roma - Tor Vergata, pelo Istituto Italo-Latino Americano e pela Associazione di Studi Sociali Latino-Americani, Antonio Gidi apresentou a proposta. E foi ainda em Roma que a Diretoria do Instituto Ibero-Americano amadureceu a ideia, incorporando-a com entusiasmo. E, em Assembleia, foi votada a proposta de se empreender um trabalho que levasse à elaboração de um Código Modelo de Processos Coletivos para Ibero-América, nos 
moldes dos já editados Códigos Modelo de Processo Civil e de Processo Penal. Ou seja, de um Código que pudesse servir não só como repositório de princípios, mas também como modelo concreto para inspirar as reformas, de modo a tornar mais homogênea a defesa dos interesses e direitos transindividuais em países de cultura jurídica comum.

Incumbidos pela Presidência do Instituto de preparar uma proposta de Código Modelo de Processos Coletivos para Ibero-América, Ada Pellegrini Grinover, Kazuo Watanabe e Antonio Gidi puseram-se a trabalhar imediatamente. Certamente foram incorporadas à proposta algumas sugestões de Antonio Gidi - mas isso muito antes da apresentação do projeto que ele chama de "original" - assim como foram incorporadas as ideias de Kazuo Watanabe e minhas.

Outros membros do grupo ampliado de especialistas em direito processual estruturado em torno da Escola Processual Paulista reagiram à posição de Gidi quanto à autoria do anteprojeto de Código Brasileiro de Processos Coletivos, demonstrando que a contenda colocava em jogo a própria imagem do grupo como autor (e ator político) coletivo e os valores atribuídos, dentro do grupo, aos capitais acadêmicos e profissionais de seus membros. Para Eurico Ferraresi (2008), doutor em direito processual pela USP sob orientação de Grinover, membro do Ministério Público de São Paulo e de grupos de trabalhos responsáveis pela elaboração do referido anteprojeto,

[...] exige-se de quem quer que se disponha a elaborar uma proposta de alteração legislativa uma importante dose de "vivência". Os membros do Ministério Público, sem dúvida alguma, têm muito a dizer, principalmente pela experiência no exercício das ações coletivas, de uma forma pioneira e audaz. Os advogados, da mesma forma, têm grande participação na construção dos processos coletivos, uma vez que - também corajosamente - não permitiram que no seio de processos coletivos fossem cometidos excessos e abusos. A magistratura também se aperfeiçoou, na medida em que os juízes assimilaram essa nova dimensão. Todas essas experiências são válidas e devem ser consideradas e respeitadas. Insistimos: são "vivências". Conforme exposto no Anteprojeto de Código Brasileiro de Processos Coletivos, contribuíram na sua formação todos os setores da sociedade: Ministério Público, Advocacia, Magistratura, entidades da sociedade civil etc.

Para Aluisio Gonçalves de Castro Mendes (2008), juiz federal, professor de direito processual da Universidade do Estado do Rio de Janeiro e membro do IBDP, 
Não me parecem combinar a preocupação com valores sociais e de solidariedade, que devem estar presentes em qualquer estatuto de processos coletivos, bem como a humildade nos estudos, com a postura de soberba e individualismo. Como já tive a oportunidade de escrever, o desenvolvimento do Direito Processual Coletivo é fruto de uma longa caminhada.

Como se vê nas manifestações citadas, a contenda entre Gidi e Grinover mobilizou os membros da Escola Processual Paulista e do IBDP, inclusive em seus desdobramentos judiciais. Em junho de 2008, Grinover protocolou pedido de explicações de Gidi no II Juizado Especial Criminal do Rio de Janeiro, fazendo-se representar judicialmente, entre outros advogados, por Gustavo Henrique Righi Ivahy Badaró, professor do Departamento de Direito Processual da USP e seu orientando nos cursos de mestrado e de doutorado realizados naquela universidade. No mesmo mês e ano, Grinover ingressou com ação judicial de indenização contra Gidi, sendo representada judicialmente por outro expoente da nova geração da Escola Processual Paulista, ex-orientando de Cândido Rangel Dinamarco e professor do Departamento de Direito Processual da USP, Flávio Luiz Yarshell (mencionado no Diagrama 1).

A decisão de primeira instância foi favorável a Gidi, tendo entendido o juiz que "a mera crítica literária, sugestão, posicionamento doutrinário, opinião, o debate ideológico ou a discussão acadêmica vazada na obra noticiada, mesmo que acirrada ou de índole unilateral, só por si, não constituíram ato-fato ilícito ou tampouco ofensa à honra ou a psique" (TJSP, 2008). Em decisão de segunda instância, respondendo a recurso apresentado por Grinover, o Tribunal de Justiça de São Paulo confirmou a decisão de primeira instância e o entendimento de que as críticas de Gidi foram feitas dentro dos limites aceitáveis da liberdade de expressão. Ao mesmo tempo que reconheceu a posição de prestígio de Grinover, a decisão de segunda instância (TJSP, 2013, p. 5) expôs a relatividade daquela posição diante de críticos e das divergências próprias do campo intelectual: "A autora, jurista de reconhecido brilhantismo, é pessoa notória no meio acadêmico, e por isso sujeita a exposição e críticas relacionadas às suas atividades e ao seu trabalho intelectual".

O episódio da contenda entre Gidi e Grinover ilustra com clareza as diferenças entre grupos intelectuais reduzidos e ampliados - analisados por Mannheim - e demonstra como as relações entre os membros do grupo 
íntimo definem sua posição de poder e as hierarquias internas ao campo de especialistas em direito processual. Mostra, ainda, que, por mais consolidado que seja um grupo intelectual de poder nas posições dominantes, um campo intelectual é um espaço de lutas, como outros campos sociais, e que essas lutas se desenvolvem nas franjas do domínio do grupo dominante e nos movimentos de ascensão e declínio de agentes no campo. Segundo Bourdieu (2004, p. 32-3):

A luta científica é uma luta armada entre adversários que possuem armas tão potentes e eficazes quanto o capital científico coletivamente acumulado no e pelo campo (portanto, em estado incorporado em cada um dos agentes) seja mais importante e que estejam de acordo ao menos para invocar, como uma espécie de árbitro último, o veredicto da experiência, isto é, do "real".

É, portanto, na transição do grupo íntimo para o grupo ampliado, ou seja, do núcleo duro da Escola Processual Paulista para o conjunto de associados do IBDP que o campo dessas lutas se amplia, aumentando a probabilidade de conflitos pelo acesso às comissões de reforma legislativa ou em torno dos produtos dessas comissões. O próprio IBDP, conforme se consolida institucionalmente como espaço de congregação de especialistas e de circulação de capitais simbólicos, se torna um palco para essas lutas. Além disso, não se pode ignorar a emergência de agentes externos ao órgão capazes de alcançar posições de influência nos debates e nos processos de elaboração legislativa.

É revelador, nesse sentido, o histórico da elaboração do Anteprojeto de Código de Processo Civil por uma comissão de juristas, constituída pelo Senado Federal para a substituição do código elaborado por Buzaid em 1973, bem como a análise da própria composição do grupo. Conforme o Quadro 2, dos doze membros da comissão, seis informam em seus currículos sua associação ao $\mathrm{IBDP}^{14}$; destes, porém, somente quatro realizaram seus estudos de direito processual nos departamentos acadêmicos associados ao núcleo histórico da Escola Processual Paulista (FDUSP e PUC-SP). Apesar

\footnotetext{
${ }^{4}$ Obviamente, a ausência de informação não significa necessariamente a não associação ao IBDP. Porém, trabalho aqui com a ideia de que a seleção, pelo autor da biografia ou do currículo, de elementos de sua trajetória é um indicativo do valor atribuído ao elemento escolhido para figurar entre as informações disponíveis ao público (e, por contraste, a omissão de certa informação revelaria seu baixo valor simbólico). Para uma crítica da construção de currículos e biografias no estudo de elites jurídicas, ver Almeida (2010, cap. 2)
} 
disso, é possível identificar nos egressos da Universidade do Estado do Rio de Janeiro (instituição do conhecido processualista José Carlos Barbosa Moreira, professor aposentado daquela universidade e membro honorário do IBDP) e da Universidade Federal do Rio Grande do Sul (na figura do membro da comissão Adroaldo Furtado Fabrício) desdobramentos da Escola Processual Paulista para além daquelas duas instituições de ensino originais (Paula, 2002).

Quadro 2 - Trajetórias acadêmicas e profissionais, participação em reformas anteriores e pertencimento ao IBDP dos membros da Comissão de Elaboração do Anteprojeto de Código de Processo Civil

\begin{tabular}{|c|c|c|c|c|}
\hline nome & $\begin{array}{l}\text { trajetória } \\
\text { acadêmica }\end{array}$ & $\begin{array}{l}\text { trajetória } \\
\text { profissional }\end{array}$ & $\begin{array}{c}\text { participação em } \\
\text { reformas legislativas } \\
\text { anteriores }\end{array}$ & $\begin{array}{l}\text { membro do } \\
\text { IBDP }\end{array}$ \\
\hline Luiz Fux & $\begin{array}{c}\text { Bacharel (1976), } \\
\text { doutor (2009) e livre- } \\
\text {-docente (1999) pela } \\
\text { Universidade Estadual } \\
\text { do Rio de Janeiro } \\
\text { (Uerj); professor livre- } \\
\text {-docente e titular, e } \\
\text { chefe do Departa- } \\
\text { mento de Direito } \\
\text { Processual da Uerj; } \\
\text { professor da PUC-RJ. }\end{array}$ & $\begin{array}{l}\text { Juiz de direito; } \\
\text { ministro do Superior } \\
\text { Tribunal de Justiça; } \\
\text { ministro do STF. }\end{array}$ & $\begin{array}{l}\text { Membro da comissão } \\
\text { estadual legislativa que } \\
\text { instituiu os juizados } \\
\text { especiais no Estado do Rio } \\
\text { de Janeiro }\end{array}$ & Não informado. \\
\hline $\begin{array}{l}\text { Tereza } \\
\text { Arruda Alvim } \\
\text { Wambier }\end{array}$ & $\begin{array}{l}\text { Bacharel (1980), } \\
\text { mestre (1985), } \\
\text { doutora (1990) e livre- } \\
\text {-docente (2004) pela } \\
\text { PUC-SP; professora da } \\
\text { PUC-SP, da PUC-PR, } \\
\text { da Universidade Para- } \\
\text { naense, Universidade } \\
\text { Tuiuti do Paraná e das } \\
\text { Faculdades Integradas } \\
\text { de Curitiba. }\end{array}$ & $\begin{array}{c}\text { Advogada; consultora } \\
\text { jurídica. }\end{array}$ & Não informado. & Sim. \\
\hline $\begin{array}{l}\text { Adroaldo Fur- } \\
\text { tado Fabrício }\end{array}$ & $\begin{array}{l}\text { Bacharel (1957), } \\
\text { doutor e livre-docente } \\
\text { (1977) pela UFRGS; } \\
\text { professor titular da } \\
\text { UFRGS. }\end{array}$ & $\begin{array}{c}\text { Juiz de direito; } \\
\text { desembargador do } \\
\text { Tribunal de Justiça } \\
\text { do Rio Grande do Sul; } \\
\text { advogado. }\end{array}$ & Não informado. & Sim. \\
\hline
\end{tabular}


Quadro 2 - Trajetórias acadêmicas e profissionais, participação em reformas anteriores e pertencimento ao IBDP dos membros da Comissão de Elaboração do Anteprojeto de Código de Processo Civil (continuação)

\begin{tabular}{|c|c|c|c|c|}
\hline nome & $\begin{array}{l}\text { trajetória } \\
\text { acadêmica }\end{array}$ & $\begin{array}{l}\text { trajetória } \\
\text { profissional }\end{array}$ & $\begin{array}{l}\text { participação em } \\
\text { reformas legislativas } \\
\text { anteriores }\end{array}$ & $\begin{array}{l}\text { membro do } \\
\text { IBDP }\end{array}$ \\
\hline $\begin{array}{l}\text { Benedito Pe- } \\
\text { reira Cerezzo } \\
\quad \text { Filho }\end{array}$ & $\begin{array}{l}\text { Bacharel (1994) pela } \\
\text { Faculdade de Direito } \\
\text { de Marília, mestre } \\
\text { (1999) e doutor (2002) } \\
\text { pela Universidade } \\
\text { Federal do Paraná } \\
\text { (UFPR). Professor da } \\
\text { Faculdade de Direito } \\
\text { de Ribeirão Preto da } \\
\text { USP, da Universidade } \\
\text { Estadual Norte do } \\
\text { Paraná, do Instituto } \\
\text { de Ensino Superior } \\
\text { de Brasília, das } \\
\text { Faculdades Adaman- } \\
\text { tinenses Integradas e } \\
\text { da Fundação Eurípides } \\
\text { Soares da Rocha. }\end{array}$ & Advogado. & Não informado. & Não informado \\
\hline Bruno Dantas & $\begin{array}{l}\text { Bacharel (2002) pela } \\
\text { Universidade Católica } \\
\text { de Brasília, mestre } \\
\text { (2007) e doutor (2013) } \\
\text { pela PUC-SP; professor } \\
\text { do Instituto Brasiliense } \\
\text { de Direito Público. }\end{array}$ & $\begin{array}{l}\text { Advogado; consultor } \\
\text { legislativo do Senado } \\
\text { Federal; membro do } \\
\text { CNJ e do Ministério } \\
\text { Público. }\end{array}$ & $\begin{array}{l}\text { Coordenador da assessoria } \\
\text { técnica da Comissão } \\
\text { Mista Especial do Congresso } \\
\text { Nacional para a Reforma do } \\
\text { Judiciário. }\end{array}$ & Não informado. \\
\hline $\begin{array}{l}\text { Elpídio Doni- } \\
\text { zetti Nunes }\end{array}$ & $\begin{array}{l}\text { Bacharel (1984) e } \\
\text { mestre (2002) pela } \\
\text { PUC-MG; professor da } \\
\text { Universidade Federal } \\
\text { de Minas Gerais, da } \\
\text { Universidade Federal } \\
\text { de Uberaba, da PUC- } \\
\text {-MG, da Universidade } \\
\text { do Oeste de Santa } \\
\text { Catarina e do Centro } \\
\text { Universitário Newton } \\
\text { Paiva. }\end{array}$ & $\begin{array}{l}\text { Promotor de justiça; } \\
\text { juiz de direito; desem- } \\
\text { bargador; advogado. }\end{array}$ & Não informado. & Não informado. \\
\hline
\end{tabular}


Quadro 2 - Trajetórias acadêmicas e profissionais, participação em reformas anteriores e pertencimento ao IBDP dos membros da Comissão de Elaboração do Anteprojeto de Código de Processo Civil (continuação)

\begin{tabular}{|c|c|c|c|c|}
\hline nome & $\begin{array}{l}\text { trajetória } \\
\text { acadêmica }\end{array}$ & $\begin{array}{l}\text { trajetória } \\
\text { profissional }\end{array}$ & $\begin{array}{l}\text { participação em } \\
\text { reformas legislativas } \\
\text { anteriores }\end{array}$ & $\begin{array}{l}\text { membro do } \\
\text { IBDP }\end{array}$ \\
\hline $\begin{array}{l}\text { Humberto } \\
\text { Theodoro } \\
\text { Júnior }\end{array}$ & $\begin{array}{l}\text { Bacharel (1961) pela } \\
\text { Faculdade do Triân- } \\
\text { gulo Mineiro, doutor } \\
\text { (1987) pela UFMG; } \\
\text { professor da UFMG. }\end{array}$ & $\begin{array}{l}\text { Juiz de direito; desem- } \\
\text { bargador; advogado. }\end{array}$ & Não informado. & Sim. \\
\hline $\begin{array}{l}\text { Jansen Fialho } \\
\text { de Almeida }\end{array}$ & $\begin{array}{l}\text { Bacharelado e outras } \\
\text { titulações não infor- } \\
\text { mados. Professor da } \\
\text { Universidade Paulista, } \\
\text { do Centro Universitário } \\
\text { do Distrito Federal e } \\
\text { da Universidade Gama } \\
\text { Filho. }\end{array}$ & $\begin{array}{l}\text { Advogado; procurador } \\
\text { do Distrito Federal; } \\
\text { juiz de direito. }\end{array}$ & Não informado. & Não informado. \\
\hline $\begin{array}{l}\text { José Miguel } \\
\text { Garcia Medina }\end{array}$ & $\begin{array}{c}\text { Bacharel (1994) } \\
\text { pela Universidade } \\
\text { Estadual de Maringá } \\
\text { (UEM), mestre (1997) } \\
\text { e doutor (2001) pela } \\
\text { PUC-PR. Professor da } \\
\text { UEM e da Universidade } \\
\text { Paranaense. }\end{array}$ & Advogado. & Não informado. & Sim. \\
\hline $\begin{array}{l}\text { José Roberto } \\
\text { dos Santos } \\
\text { Bedaque }\end{array}$ & $\begin{array}{c}\text { Bacharel (1977) } \\
\text { pela Universidade } \\
\text { de Taubaté, mestre } \\
\text { (1989), doutor (1994) } \\
\text { e livre-docente (1998) } \\
\text { pela FDUSP. Professor } \\
\text { titular da USP. }\end{array}$ & $\begin{array}{l}\text { Promotor de justiça; } \\
\text { procurador de justiça; } \\
\text { desembargador. }\end{array}$ & Não informado. & Sim. \\
\hline $\begin{array}{l}\text { Marcus Viní- } \\
\text { cius Furtado } \\
\text { Coelho }\end{array}$ & $\begin{array}{c}\text { Bacharel (1993) pela } \\
\text { Universidade Federal } \\
\text { do Piauí. }\end{array}$ & $\begin{array}{l}\text { Advogado; procurador } \\
\text { geral do estado do } \\
\text { Piauí. }\end{array}$ & Não informado. & Não informado. \\
\hline $\begin{array}{l}\text { Paulo Cezar } \\
\text { Pinheiro Car- } \\
\text { neiro }\end{array}$ & $\begin{array}{l}\text { Bacharel (1972) e } \\
\text { doutor (data não } \\
\text { informada) pela Uerj; } \\
\text { professor da Uerj. }\end{array}$ & $\begin{array}{l}\text { Procurador do Estado } \\
\text { do Rio de Janeiro; } \\
\text { advogado. }\end{array}$ & Não informado. & Sim. \\
\hline
\end{tabular}

Fontes: CNPq (2014); Elpídio Donizzeti Advogados (2014); Fabrício Advogados S/C (2014); IBDP (2014); Senado Federal (2014); STF (2014). 
Por outro lado, chama a atenção a presença de um membro da comissão (Benedito Pereira Cerezzo Filho) egresso da Universidade Federal do Paraná, instituição na qual estaria baseada, segundo Paula (2002), a chamada "Escola Paranaense" do direito processual, organizada em torno de figuras como Moniz Aragão e Luiz Guilherme Marinoni (ambos membros do IBDP, sendo o segundo orientador de mestrado e doutorado de Cerezzo Filho). Percebe-se também a presença de membros da comissão que, embora possuam títulos acadêmicos (o capital científico "puro"), não possuem posições superiores em carreira acadêmica (o capital científico-institucional, entendido como prestígio e poder institucional no campo acadêmico). Há também membros sem titulação acadêmica de mestrado ou doutorado informada, com conexões quase exclusivas com o campo profissional do direito: Jansen Fialho de Almeida, juiz de direito; e Marcus Vinícius Furtado Coelho, advogado e dirigente nacional da OAB. Por fim, é importante notar a juventude e a ausência de experiências anteriores em reformas legislativas da maior parte dos membros dessa comissão.

\section{Intelectuais e política}

Além da análise da composição da comissão de elaboração do Anteprojeto, é preciso levar em conta ainda os conflitos entre o grupo íntimo da Escola Processual Paulista e a referida comissão em torno dos méritos da proposta legislativa. Após a aprovação do Anteprojeto na Câmara dos Deputados, Ada Pellegrini Grinover expôs publicamente diversas críticas à proposta de reforma do Código de Processo Civil elaborada por sua comissão. Segundo a processualista, o anteprojeto não significaria uma reforma, mas apenas uma "mudança", razão pela qual ela prometeu apresentar um substitutivo, de maneira individual e paralela ao processo legislativo conduzido pelo Congresso Nacional com o apoio da comissão (Ghirello, 2011).

Nesse aspecto, é importante analisar a posição de Grinover em relação ao próprio processo legislativo e ao papel dos especialistas e dos políticos eleitos na elaboração de normas:

Seria preferível o que se faz na Itália e na França: uma lei quadro sai do executivo - de especialistas - e fixa as diretrizes principiológicas ou até, em determinadas matérias, mais específicas, que o Congresso tem que levar em conta para legislar. É a lei quadro ou a lei de delegação em que os especialistas do executivo, nem sempre são ótimos, 
mas pelo menos são considerados especialistas da matéria.

[...] Se for implantado esse processo legislativo, a ideia é que o Ministério da Justiça crie comissões especialistas, e depois o Congresso apenas detalha e especifica. Esse seria o sistema ideal, mas não é o nosso. Qualquer deputado e qualquer senador têm iniciativa para fazer uma proposta de projeto de lei. E com esse cipoal de leis que aparece, uma contradizendo a outra, uma revogando a outra, não dá para saber qual está em vigor (Grinover, 2012).

O processo de elaboração legislativa proposto por Grinover é, na verdade, aquele historicamente empregado no Brasil para a reforma do direito processual (e da justiça, por consequência esperada), no qual o grupo intelectual ao qual ela esteve ligada sempre teve protagonismo, na condição de "especialistas da matéria", conforme ela defende. Nesse sentido, o anteprojeto criticado por ela foi uma exceção pioneira, uma vez que a iniciativa foi do Senado (e não do Ministério da Justiça), a comissão de especialistas teve composição ampla e heterogênea, com presidência de um ministro de tribunal superior e com a submissão da proposta dos especialistas a diversas tentativas de alteração feita por parlamentares.

Nesse aspecto, veja-se também a crítica de Grinover (2012) às contingências e aos arranjos próprios da política, especialmente às intervenções do relator do anteprojeto na Câmara dos Deputados, deputado Sérgio Barradas (PT-BA), e de sua suposta relação com um processualista externo à comissão (e, possivelmente, externo ao grupo intelectual do qual ela faz parte):

[...] a situação política é que está muito confusa na Câmara. O Sérgio Barradas, relator da comissão, que está revendo o projeto de lei na Câmara, é suplente de deputado. Ele já teve de sair do cargo uma vez porque o titular reassumiu a função. Nessa época, ele foi substituído pelo Paulo Teixeira, os dois do PT. O Paulo Teixeira deu uma abertura maior do que o Barradas. Ele ouviu mais especialistas, fez mais audiências públicas. Agora, o Barradas reassumiu, e ele está ligado a um professor de Processo Civil da Bahia, muito bem qualificado, mas que, infelizmente, não consegue trabalhar em equipe. Então, na verdade, o primeiro trabalho que traz o nome do Barradas é um projeto feito por uma só pessoa.

Também nesse episódio, portanto, percebem-se as tensões entre especialistas e entre eles e o Estado no trabalho de elaboração legislativa do direito processual. A proposta de elaboração legislativa de Grinover defende o 
predomínio de especialistas sobre a representação política popular e, mais do que isso, sugere uma seleção mais controlada desses especialistas para a formação de comissões, via Poder Executivo. Para o bem ou para o mal, a experiência de elaboração do anteprojeto de Código de Processo Civil, por outro lado, mostra uma abertura maior do processo legislativo a influências políticas diversas, à representação de uma maior diversidade de posições institucionais, profissionais e acadêmicas do campo jurídico e, ainda, a uma maior interferência da política profissional sobre a condução da proposta de novo texto legal. ${ }^{15}$

\section{Considerações finais}

Busquei analisar, em primeiro lugar, como o direito processual é uma dimensão política relativamente autônoma da administração e da reforma da justiça no Brasil. Essa autonomia relativa se baseia na unidade da legislação processual e em sua possibilidade de reforma por maioria legislativa simples, em contraposição à fragmentação institucional e profissional do sistema de justiça, cujo redesenho institucional depende de reformas constitucionais ou de mudanças de legislação infraordinária que enfrentam atores corporativos fortemente mobilizados.

Essa autonomia relativa também de baseia na existência de uma comunidade de especialistas em direito processual, mobilizados pelo Estado para a reforma dessa dimensão do sistema de justiça. O estudo em profundidade da Escola Processual Paulista ajuda a compreender como um grupo intelectual específico se constitui, cria uma identidade e alcança predomínio sobre outros grupos no acesso às comissões de reforma legislativa e na determinação do conteúdo das reformas. Esse predomínio depende da ocupação de posições acadêmicas de destaque, da conexão desses intelectuais com o mundo prático-profissional do direito e com as posições de liderança institucional do sistema de justiça, mas também do esforço de coesão interna do grupo e de sua reprodução, baseado na construção de sua narrativa fundadora e de um discurso ao mesmo tempo político e acadêmico sobre suas especificidades científicas e sua missão pública.

Porém, o estudo da participação da Escola Processual Paulista nas reformas recentes do direito processual brasileiro mostra também que a

15 O presente artigo foi concluído antes da aprovação definitiva do Anteprojeto de Código de Processo Civil. O novo Código foi finalmente sancionado em 16 de março de 2015. 
passagem de um grupo íntimo para um grupo ampliado, por meio da sua institucionalização (no caso, por meio do IBDP), se por um lado permite a expansão da rede de relações e da influência do grupo, por outro faz surgir conflitos sobre o pertencimento ao grupo e de concorrência pelo acesso às comissões de reforma legislativa. As polêmicas envolvendo membros da Escola Processual Paulista e do IBDP nos episódios de elaboração do Código de Processos Coletivos e do Anteprojeto do Código de Processo Civil ilustram as dinâmicas desse tipo de conflito.

Nesse sentido, e conforme demonstra a experiência da comissão de reforma do Código de Processo Civil instituída pelo Senado (e sua crítica por uma expoente da Escola Processual Paulista), o foco da questão passa do campo jurídico para o campo político, uma vez que a iniciativa de reformas e a seleção de especialistas dependem em grande parte dos poderes Executivo e Legislativo, cujas relações com os "teóricos" e os "práticos" do direito podem determinar a maior ou menor abertura do processo de reforma à interferência de grupos intelectuais concorrentes, de interesses corporativos e da representação política.

\section{Referências}

ALCALÁ-ZAMORA Y CASTILLO, Niceto (1958). "Escola Processual de São Paulo”. Revista da Universidade Católica. São Paulo.

ALMEIDA, Frederico N. R. de (2006). A advocacia e o acesso à justiça no estado de São Paulo (1980-2005). Dissertação (mestrado) em Ciência Política. São Paulo: FFLCH-USP.

(2010). A nobreza togada: as elites jurídicas e a política da justiça no Brasil. Tese (doutorado) em Ciência Política. São Paulo: FFLCH-USP. (2014). "As elites da justiça: instituições, profissões e poder na política da justiça brasileira”. Revista de Sociologia e Política, v. 22, n. 52, p. 77-95. ALVES, José Carlos Moreira (2003). "Alfredo Buzaid: Uma vida dedicada ao direito”, em RUFINO, A. G.; PENTEADO, J. C. (org.). Grandes juristas brasileiros. São Paulo: Martins Fontes.

ARANTES, Rogério Bastos (2002). Ministério Público e política no Brasil. São Paulo: Educ/Sumaré/Fapesp.

ABDPC - ASSOCIAÇÃO BRASILEIRA DE DIREITO PROCESSUAL CIVIL (2014). http://www.abdpc.org.br. Acesso em: 25 jul. 2014.

BOURDIEU, Pierre (2004). Os usos sociais da ciência: por uma sociologia clínica do campo científico. São Paulo: Editora Unesp. 
(2007). O poder simbólico. 10. ed. Rio de Janeiro: Bertrand Brasil.

CINTRA, Antonio Carlos de Araújo et al. (1998). Teoria geral do processo. 14. ed. São Paulo: Malheiros.

CNPq - CONSELHO NACIONAL DE DESENVOLVIMENTO CIENTÍFICO E TECNOLÓGICO (2014). Plataforma Lattes [online]. Disponível em: http://lattes.cnpq.br. Acesso em: 28 jul. 2014.

COSER, Ivo (2008). Visconde do Uruguai: centralização e federalismo no Brasil 1823-1866. Belo Horizonte: Editora da UFMG/; Rio de Janeiro: Iuperj.

CRUZ E TUCCI, José Rogério (2003). “Antônio Joaquim Ribas”, em RUFINO, A. G. \& PENTEADO, J. C. (orgs.). Grandes juristas brasileiros. São Paulo: Martins Fontes.

CUNHA, Luciana Gross \& ALMEIDA, Frederico de (2012). "Justiça e desenvolvimento econômico na Reforma do Judiciário brasileiro", em SCHAPIRO, M. G. \& TRUBEK, D. M. (orgs.). Direito e desenvolvimento: um diálogo entre os Brics. São Paulo: Saraiva.

DEZALAY, Yves \& TRUBEK, David (1996). "A reestruturação global e o direito: a internacionalização dos campos jurídicos e a criação dos espaços transnacionais", em FARIA, J. E. (org.). Direito e globalização econômica: implicações e perspectivas. São Paulo: Malheiros.

ELPÍDIO DONIZETTI ADVOGADOS (2014). Currículo de Elpídio Donizetti [online]. Disponível em: http://www.elpidiodonizetti.com/equipe/8. Acesso em: 25 jul. 2014.

ENGELMANN, Fabiano (2006). Sociologia do campo jurídico: juristas e usos do direito. Porto Alegre: Sergio Antonio Fabris.

ESCOLA NACIONAL DA MAGISTRATURA; INSTITUTO BRASILEIRO DE DIREITO PROCESSUAL; SECRETARIA DE REFORMA DO JUDICIÁRIO DO MINISTÉRIO DA JUSTIÇA (2006). Curso de atualização em direito processual civil: $3^{a}$ etapa da Reforma do CPC. Brasília: Ministério da Justiça.

FABRÍCIO ADVOGADOS S/C (2014). Currículo de Adroaldo Furtado Fabrício. Disponível em: http://www.fabricioadvogados.com.br/tcurriculo. htm. Acesso em: 25 jul. 2014.

FALCÃO, Joaquim (2005). "Estratégias para a reforma do judiciário", em RENAULT, S. R. T. \& BOTTINI, P. (orgs.). Reforma do Judiciário. São Paulo: Saraiva. 
FERRARESI, Eurico (2008). O “Código de Processo Civil Coletivo" de Antonio Gidi (datado de 5 de junho de 2008) [online]. Disponível em: http://www. direitoprocessual.org.br/site/index.php?m=noticia\&id=256\&subm=\&w idth $=\&$ mostraData.

GHIRELLO, Mariana (2011). "Novo CPC não é reforma, é mudança pontual, diz Ada Pellegrini Grinover". Última Instância, 23 jun. [online]. Disponível em: http://ultimainstancia.uol.com.br/conteudo/noticias/51988/ novo+cpp+nao+e+reforma + e+mudanca + pontual+diz+ada+pellegrini +grinover.shtml. Acesso em: 23 jun. 2014.

GIDI, Antonio (2008). Rumo a um Código de Processo Civil Coletivo: a codificação das ações coletivas no Brasil. Rio de Janeiro: Forense.

GRINOVER, Ada Pellegrini (org.) (1982). Estudos de direito processual em homenagem a José Frederico Marques em seu $70^{\circ}$ aniversário. São Paulo: Saraiva.

GRINOVER, Ada Pellegrini (2005). "A necessária reforma infraconstitucional”, em RENAULT, S. R. T. \& BOTTINI, P. (org.). Reforma do Judiciário. São Paulo: Saraiva.

(2008). Resposta a um convite (datada de 30 de maio de 2008) [online]. Disponível em: http://www.direitoprocessual.org.br/site/index. php? $\mathrm{m}=$ noticia\&id $=253 \&$ subm $=\&$ width $=\&$ mostraData. Acesso em: 10 dez. 2009.

(2012). "Se CPC ficar como está, melhor não sair" (entrevista a Elton Bezerra e Lilian Scocuglia). Consultor Jurídico, 21 out. [online]. Disponível em: http://www.conjur.com.br/2012-out-21/entrevista-ada-pellegrini-grinover-processualista. Acesso em: 24 jun. 2014.

INSTITUTO BRASILEIRO DE DIREITO PROCESSUAL (2014). http:// www.direitoprocessual.org.br. Acesso em: 25 jul. 2014.

LIMA LOPES, José Reinaldo de (2001). "Uma introdução à história social e política do processo", em WOLKMER, A. C. (org.). Fundamentos de história do direito. 2. ed. Belo Horizonte: Del Rey.

LIPSKY, Michael (1980). Street-level bureaucracy: dilemmas of the individual in public services. New York: Russel Sage Foundation.

MANNHEIM, Karl (1957). Ensayos de sociologia de la cultura. Madrid: Aguilar.

MENDES, Aluisio Gonçalves de Castro (2008). Do individual ao coletivo: os caminhos do direito processual brasileiro [online]. Disponível em: 
http://www.direitoprocessual.org.br/site/index.php?m=noticia\&id=254

\&subm=\&width=\&mostraData. Acesso em: 10 dez. 2009.

MICELI, Sergio (1979). Intelectuais e classe dirigente no Brasil (1920-1945).

São Paulo: Difel.

(1988). A elite eclesiástica brasileira. Rio de Janeiro: Bertrand Brasil. (1999). "Intelectuais brasileiros", em MICELI, S. (org.). O que ler na ciência social brasileira (1970-1995). v. 2. São Paulo: Sumaré/Anpocs; Brasília: Capes.

NALINI, José Renato (2003). "José Frederico Marques: o homem continente", em NEGRETE ROMERO, Roberto (s.d.). Niceto Alcalá-Zamora y Castillo (1906-1985) [online]. Disponível em: http://derecho.procesal.unam.mx/ maestros/pdf/Niceto_Alcala.pdf. Acesso em: 10 dez. 2009.

NOBRE, Marcos (2005). “O que é pesquisa em direito?”, em NOBRE, M. et al. (orgs.). O que é pesquisa em Direito? São Paulo: Quartier Latin.

NUNES LEAL, Victor (1975). Coronelismo, enxada e voto: o município e o regime representativo no Brasil. 2. ed. São Paulo: Alfa-Omega.

OLIVEIRA, Luciano (2004). "Não fale do Código de Hamurábi! A pesquisa sociojurídica na pós-graduação em direito", em OLIVEIRA, L. Sua Excelência o Comissário e outros ensaios de sociologia jurídica. Rio de Janeiro: Letra Legal.

PAULA, Jônatas Luiz Moreira de (2002). História do direito processual brasileiro: das origens lusas à Escola Crítica do Processo. Barueri (SP): Manole.

RUFINO, Almir Gasquez \& PENTEADO, Jacques de Camargo (orgs.) (2003). Grandes juristas brasileiros. São Paulo: Martins Fontes. (2006). Grandes juristas brasileiros. Livro 2. São Paulo: Martins Fontes.

SADEK, Maria Tereza Aina (1999). "O sistema de justiça”, em SADEK, M. T. A. (org.). O sistema de justiça. São Paulo: Idesp/Sumaré. . (2004a). "El poder judicial y la magistratura como actores políticos", em RODRIGUES, L. M. \& SADEK, M. T. A. El Brasil de Lula: diputados y magistrados. Buenos Aires: La Crujía.

SADEK, Maria Tereza (2004b). "Judiciário: mudanças e reformas". Estudos Avançados, v. 18, n. 51, p. 79-101.

SCHNEIDER, Marília (2007). Justiça e política na Primeira República: história do Tribunal de Justiça de São Paulo. São Paulo: Singular. 
SECRETARIA DA REFORMA DO JUDICIÁRIO DO MINISTÉRIO DA JUSTIÇA (2005a). Seminário "A Reforma do Processo Civil Brasileiro", 29 mar. $-1^{\circ}$ abr. Brasília: Ministério da Justiça.

(2005b). Seminário "A Reforma do Processo Penal Brasileiro", 7-9 jun. 2005. Brasília: Ministério da Justiça.

(2005c). Seminário "A Reforma do Processo Trabalhista Brasileiro", 19-20 maio 2005. Brasília: Ministério da Justiça.

SENADO FEDERAL (2010). Anteprojeto do novo Código de Processo Civil [online]. Disponível em: http://www.senado.gov.br/senado/novocpc/ pdf/anteprojeto.pdf. Acesso em: 23 mar. 2014.

SINHORETTO, Jacqueline \& ALMEIDA, Frederico de (2013). "Reforma do Judiciário: entre legitimidade e eficiência”, em SILVA, F. G. \& RODRIGUEZ, J. R. (orgs.). Manual de sociologia jurídica. São Paulo: Saraiva. STF - SUPREMO TRIBUNAL FEDERAL (2014). http://www.stf.jus.br. Acesso em: 6 jun. 2014.

TJSP - TRIBUNAL DE JUSTIÇA DO ESTADO DE SÃO PAULO (2013). Acórdão da apelação n. 9113728-51.2009.8.26.0000, voto n. 3534. [online]. Disponível em: http://s.conjur.com.br/dl/decisao-nega-indenizacao-pedida-ada.pdf. Acesso em: 20 jun. 2014.

(2008). Sentença do processo n. 583.00.2008.158923-0, da 26a Vara Cível do Foro Central da Comarca de São Paulo [online]. Disponível em: http://www.gidi.com.br/Ada\%20P.\%20Grinover/8\%20Sentença\%20 de\%201o\%20grau.pdf. Acesso em: 30 jul. 2014.

TJMG - TRIBUNAL DE JUSTIÇA DO ESTADO DE MINAS GERAIS (2014). Currículo de Elpídio Donizetti [online]. Disponível em: http://ftp. tjmg.jus.br/institucional/desembargadores/curriculum/elpidiodonizetti. html. Acesso em: 25 jul. 2014.

TUCCI, Rogério Lauria (2006). “Moacyr Amaral Santos: político, mestre, jurista e magistrado a serviço da nação”, em RUFINO, A. G. \& PENTEADO, J. C. (orgs.). Grandes juristas brasileiros. Livro 2. São Paulo: Martins Fontes.

VIDIGAL, Luís Eulálio de Bueno (1998 [1974]). “Prefácio da 1a edição”, em CINTRA, Antonio Carlos de Araújo et al. Teoria geral do Processo. 14. ed. São Paulo: Malheiros.

WAGNER JR., Luiz Guilherme da Costa et al. (2006). Poder Judiciário e carreiras jurídicas. Belo Horizonte: Del Rey. 
WERNECK VIANNA, Luiz et al. (1999). A judicialização da política e das relações sociais no Brasil. Rio de Janeiro: Revan.

YARSHELL, Flávio Luiz \& MORAES, Maurício Zanóide de (orgs.) (2005). Estudos em homenagem à professora Ada Pellegrini Grinover. São Paulo: DPG.

\section{Resumo}

O artigo busca demonstrar a relevância política do direito processual nas reformas do sistema de justiça brasileiro, bem como o papel político exercido pelos especialistas em direito processual na concepção e na condução dessas reformas. Em um primeiro momento, examinam-se as características institucionais do sistema de justiça brasileiro, que consideram a unidade nacional da legislação processual uma vantagem comparativa em relação à fragmentação das agências burocráticas e das carreiras profissionais do mesmo sistema. Em um segundo momento, o artigo adota uma abordagem sociológica para oferecer uma explicação baseada na existência de um campo jurídico, mais amplo que as instituições formais do sistema de justiça. Nesse campo, agentes identificados como uma elite intelectual, sem necessariamente possuírem posições de liderança na estrutura estatal, mobilizam recursos de poder simbólico para garantirem acesso privilegiado aos processos políticos de reforma do sistema de justiça pela via processual.

Palavras-chave: reforma do Judiciário; direito processual; reformas do Estado; intelectuais e política; processo legislativo.

\section{Abstract}

This paper seeks to demonstrate the political importance of Procedural Law to reforms of Brazil's Judicial system, as well as the political role played by Procedural Law experts in conceiving and conducting such reforms. It starts by examining the institutional characteristics of Brazil's system, seeing the unitary character of Procedural Law in Brazil as a comparative advantage over the fragmentation of bureaucratic agencies and professional careers in that system. It then takes a sociological approach to offer an explanation based on the existence of a legal field that is broader than the formal institutions of the judicial system. In this legal field, agents, identified as an intellectual elite, without necessarily occupying leading positions in the State framework, make use of their symbolical power to achieve privileged access to the political processes of reforming the judicial system.

Keywords: judicial reform; procedural law; State reforms; intellectuals and politics; legislative process.

Recebido em 31 de julho de 2014.

Aprovado em 28 de outubro de 2014. 